Natural occurrence of aflatoxins and toxigenic fungi in rice bran oil and de-oiled bran

$$
\text { P. Jayaraman* and Indira Kalyanasundaram }{ }^{\#}
$$

${ }^{*}$ Dept. Biotech., Vel Tech. High Tech. Dr.Rangarajan Dr.Sakunthala Engg. College, Avadi, Chennai-600 062.

${ }^{\#}$ CAS in Botany, Univ. Madras, Gunidy Campus, Chennai 600 025, India

\title{
jayaramannp@gmail.com
}

Abstract: Samples of crude- and refined- rice bran oil and de-oiled bran collected from mills and local market places were analysed for the presence of aflatoxins $B_{1}$ and the causal fungi. Out of 20 crude rice bran oil and 20 refined rice bran oil samples analysed, 15 and 6 samples, respectively were positive for aflatoxins $\mathrm{B} 1$. The aflatxoin $B_{1}$ in the rice bran oil samples were in the range of trace to $956 \mathrm{ppb}$ and averaged $618 \mathrm{ppb}$. Out of 30 samples analysed, 20 samples of de-oiled bran were positive and the toxin level ranged from 7 to $144 \mathrm{ppb}$ with an average of $33 \mathrm{ppb}$. The storage fungi including toxigenic fungi present in the rice bran oil and de-oiled bran samples were Aspergillus glaucus, $A$. flavus, $A$. niger, $A$. nidulans, $A$. candidus, $A$. fumigatus, and Penicillium spp. and Gliocladium viride. In the rice bran oil samples, the fungi found were less in number (1 one to $14 \mathrm{cfu} / \mathrm{g}$ ) with an average of $2 \mathrm{cfu} / \mathrm{g}$. While, in the de-oiled bran, it was 1 to $130 \times 10^{3} \mathrm{cfu} / \mathrm{g}$ with an average of $33 \times 10^{3} \mathrm{cfu} / \mathrm{g}$ which include toxigenic $A$. flavus. About $60 \%$ of $A$. flavus from crude rice bran oil samples and $66.7 \%$ of $A$. flavus strains isolated from de-oiled bran samples were positive for aflatoxin production.

Keywords: Aflatoxins, mycotoxins, storage fungi, Aspergillus flavus, rice bran oil, de-oiled rice bran. Introduction

The present investigation is based on our earlier study which indicated that the rice bran samples of raw rice and parboiled rice were contaminated with aflatoxins along with the elaborating fungi (Jayaraman \& Kalyanasundaram, 1990; Jayaraman, 1991 \& Vincent 1999). About 4 million tonnes of proteins, 5 million tonnes of edible oil and 75,000 billion calories, besides various quantities of vitamins and minerals have already been reported to produce from rice bran for consumption of human and domestic animals (Houston, 1972; Barber, 1978). The oil yielding potential of rice bran is exploited in India and used for cooking as well as for various industrial purposes. The lipid fraction of rice bran contains mainly oleic, linoleic and palmetic acids which are excellent nutrient source. Rice bran oil contains lowest hyphocholestrolaemic activity (Rukmini, 1985). De-oiled bran contains less fat and high protein that is used in the cattle- and poultry-feeds.

Therefore, the present study focused on the aflatoxin production in rice bran oil and de-oiled bran and also identified the causal fungi which is health hazard.

Materials and methods

Samples collection

Rice bran oil: The crude rice bran oil and the refined rice bran oil were collected from oil extraction mills and local market places. They were sampled in new PET bottles pre-cleaned with alcohol and brought to the laboratory for analysis of storage fungi and aflatoxins by standard procedures. The crude rice bran oil sampleas were collected from the rice bran oil extraction mills only (2 days old storage before refining). The refined rice bran oil (edible oil) samples were collected from mills as well as from local markets (various parts of TN, Karnataka \& AP). De-oiled rice bran or de-fatted rice bran: The unused polythene bags pre-cleaned with alcohol were used for the collection of de-oiled rice bran samples. After collection, the bags were tied with rubber bands tightly to avoid contamination and labeled. The de-oiled samples were collected from the rice bran oil extraction mills located in various districts of Tamil Nadu viz. Salem, South Arcot and Trichi. The samples were analysed in the laboratory within a week of collection and ascertain for the presence of aflatoxins and toxigenic fungi.

Enumeration of toxigenic fungi

The storage mycoflora of the rice bran oil samples were analysed on Czapek's Dox agar containing 50\% sucrose by pour plate method. One $\mathrm{ml}$ aliquots of the oil samples were plated aseptically over the medium. The plates were swirled to distribute the inoculum uniformly entire surface area. To harbor the storage fungi which include toxigenic fungi, highly osmotic medium which contains $50 \%$ of sucrose in Czapek's Dox Media (Rao \& Kalyanasundaram, 1983) was used. The media included antibiotic streptopenicillin in mentioned concentration to suppress any external contamination.

The de-oiled rice bran samples were analyzed for the presence of storage mycoflora and toxigenic fungi by serial dilution plating method (Jhonson \& Curl, 1972). About $10 \mathrm{~g}$ was taken as a starter material and was diluted serially with sterile saline solution. The plates were incubated at $30+/-1^{\circ} \mathrm{C}$ for a week to develop culture mycelia followed by sporulation for identification. The Aspergillus species were identified after Raper and Fennel (1965) and the Penicillium species were after Raper et al. (1949). The quantitative pattern of storage mycoflora was expressed as number of colony forming units per gram (cfu/g) or per $\mathrm{ml}(\mathrm{cfu} / \mathrm{ml})$. The fungal species were also maintained on agar slants of normal Czapek's Dox Agar with 3\% sucrose for further work.

\section{Analyses of aflatoxins}

The reagents and solvents used for extraction and analysis in the present study were analytical grade of Emerck, Loba, BDH and Qualigens products. The standard aflatoxin B1 obtained as a free sample from National Institute of Public Health and Environmental Protection, Bilthovan, The Netherlands.

The standard AOAC method (Stoloff et al., 1971) was followed using Acetonitrile: Potassium chloride solution
Research article

(CIndian Society for Education and Environment (iSee)
"Aflatoxin in cattle feed" http://www.indjst.org
Jayaraman \& Indira Indian J.Sci.Technol. 
(90:10) for extraction followed by identification and confirmation through thin layer chromatography (TLC).

The simple screening method for aflatoxin by Seitz and Mohr (1972) using methanol as a solvent and developing the TLC in chloroform : acetone (88:12) was also was used in addition to the above procedure.

The quantitative estimation of the aflatoxin from samples was made by the spectrophotometric method described by Nabney \& Nesbitt (1965). Aflatoxin recovered in cold methanol from silica gel plate was read spectrophotometerically at $363 \mathrm{~nm}$ and $420 \mathrm{~nm}$ and the OD values were taken for calculation. The following formula was used for quantitative estimation.

$\mathrm{D} \times \mathrm{M} \times 10^{6}$

$\mathrm{E} \times 200 \times \mathrm{t}$

$\mu \mathrm{g}$ per $5 \mathrm{ml}$ of solution

Where,

D- is the corrected OD at $363 \mathrm{~nm}$ (OD

$363 \mathrm{~nm}-\mathrm{OD}$ at $420 \mathrm{~nm}$ )

$M$ - is the molecular weight of aflatoxins

$B_{1}$ i.e 312

$\mathrm{E}-$ is the molecular extinction coefficient of aflatoxin B1 $(22,000)$

$\mathrm{t}-$ is the thickness of the cuvette in $\mathrm{cm}$

Toxigenicity of fungal isolates

To screen the fungal isolates for production of aflatoxin in vitro, the fungi were cultured in slants of an agar medium containing $2 \%$ yeast extract and $15 \%$ sucrose (YES agar). Toxins were extracted from the molten agar with chloroform and assayed by TLC using toluene: ethyl acetate: $90 \%$ formic acid (6:3:1) solvent system (Bullerman, 1974). The fluorescent spots in blue and green TLC under short wavelength indicates the presence or absence of aflatoxin and the toxigenic property of the Aspergillus flavus strains.

Results

Aflatoxins

Out of 20 crude rice bran oil samples analysed, 15 were positive for aflatoxin $B_{1}$ in the concentration of 236 $\mathrm{ppb}$ to $956 \mathrm{ppb}$ with an average of $618 \mathrm{ppb}$. Of the 20 refined rice bran oil samples analysed, 6 samples were found with aflatoxin $B_{1}$ contamination of trace to $28 \mathrm{ppb}$ with an average of $20 \mathrm{ppb}$. In one sample of refined rice bran oil, aflatoxins $B_{2}, G_{1} \& G_{2}$ also were present in addition to aflatoxin $B_{1}$. Twenty of the 30 de-oiled bran rice bran samples collected were positive for aflatoxin $B_{1}$ in the range of 7 to $144 \mathrm{ppb}$ with an average of $33 \mathrm{ppb}$. Table 1 indicates the details of samples analysed and the contamination levels with aflatoxins.

\section{Toxigenic fungi}

In the crude rice bran oil samples analysed , 15 out of 20 were contaminated with fungi including Gliocladium viride, Mucor mucedo, A. flavus, A.glaucus, A.nidulans, A.niger and Penicillium $s p$. in the order of dominance. Only 4 out of 10 refined rice bran oil samples were contaminated with fungi as M. mucedo. Out of 15 isolates of $A$. flavus, 9 were positive for aflatoxins. None of the refined rice bran oil samples were found to contaminate with A.flavus. Table 2 shows the presence of storage fungi and aflatoxigenic fungi in various samples studied in the present study.

Out of 30 de-oiled bran samples analysed for fungi, all the samples were found to be contaminated with different species of storage fungi with their population ranging from 1 to $130 \times 10^{\wedge} 3 \mathrm{cfu} / \mathrm{g}$ and with an average of $33 \times 10^{\wedge} 3 \mathrm{cfu} / \mathrm{g}$. Among the species of fungi present, $A$. flavus and Penicillium sp. were dominant in occurrence. In general, $A$. flavus was recorded in almost

natural occurrence of aflatoxin B1 in various samples collected 
Otherwise, these contaminated edible oils would pose a direct health hazard to man. Since the quality of rice bran oil is more suitable to maintain better body cholesterol level, which is recommended for keeping body in good health and reduce risks of coronary heart diseases.

Although most of the aflatoxins contained in rice bran are extracted along with the oil, some quantity of toxins still remained in the de-oiled bran, and further production might occur during storage because of the occurrence of toxigenic $A$. flavus. This could have deleterious effect on cattle and poultry, when the bran is fed either directly or as an ingredient of formulated feed. There are many reports of contamination of feeds with aflatxoin and other mycotoxins, from India (Shastry et al., 1965; Jayaraman \& Kalyanasundaram, 1996).

The higher incidence of aflatoxigenic fungi and aflatoxin present in de-oiled bran (Table 2) would have contaminated the cattle-feed after formulation with various oil cakes and other agricultural commodities. The contaminated cattle-feeds may account for aflatoxin in the milk. Hence, precautionary measures are to be taken to control aflatoxin and decontamination of it in feed.

\section{Acknowledgement}

$\mathrm{PJ}$ is grateful to Dr. R. Rangarajan, the Chairman, K. V. D. Kishore Kumar, the Director and management team of Vel Tech High Tech Dr. Rangarajan Dr. Sakunthala Engineering College for their constant encouragement to do research and publications.

\section{References}

1. Abbas HK, Zablotowicz RM, Horn BW, Xie W and Shier WT (2002) Determination of aflatoxin production by Aspergillus species from the Mississippi delta by various methods. Aflatoxin Elimination Workshop Proc. 15, 110.

2. Barber S (1978) Rice bran as a potential source of food. Proc. $5^{\text {th }}$ Intl. Cong., Food Sci. \& Technol., Kyoto, September.

3. Bilgrami KS, Prasad T, Mishra RS and Sinha KK (1980) Survey and study of mycotoxin producing fungi associated with grains in the standing maize crop. Final Technical Report, ICAR Project, Bhagalpur Univ.

4. Bullerman L (1974) Inhibition of aflatoxin production by cinnamon. J. Food Sci. 39, 1163-1165.

5. Castells M, Ramos AJ, Sanchis V, Martín S (2007) Distribution of total aflatoxins in milled fractions of hulled rice. J. Agric. Food Chem. 4:55 (7), 2760.

6. Celik T, Sarimehmetoglu B and Kuplulu P (2005) Aflatoxin contamination in pasteurized milk. Vet Archive. 75, 57-65.

7. Han Eun-Mee, Hee Ra Park, Soo Jung, Kwon Ki-Sung, Lee Hyomin, Ha Mi-Sun, Kim Kyung-Mi, Ko Eun Jung, Ha Sang-Do, Hyang Sook Chun and Chung DuckHwaand Bae Dong-Ho (2006) Monitoring of aflatoxin $B_{1}$ in livestock feeds using ELISA and HPLC. J. Microbiol \& Biotech. 16, 643-646.

8. Houston DF (1972) Rice bran and polish. In: Rice: Chem. \& Technol., Houston DR (ed.), Am. Asso. of Cereal Chemists, Inc. St. Paul, Minnesota. pp: 272.

9. Isohata E, Toyoda M and Saito Y (1996) Studies on chemical analysis of mycotoxin: XIII. Determination of aflatoxin $B_{1}$ in edible oil. Bull. Natl. Inst. Hyg. Sci. (Tokyo) 6, 138-142.

10. Jayaraman $P$ (1991) Storage fungi and aflatoxin $B_{1}$ in rice with reference to parboiling and milling. Ph.D. Thesis, Univ. of Madras.

11. Jayaraman P and Kalyanasundaram I (1990) Natural occurrence of toxigenic fungi and mycotoxins in rice bran. Mycopathologia. 110, 81-85.

12. Jayaraman $P$ and Kalyanasundaram I (1994) A comparison of bran from parboiled and raw rice: Nutrient content and aflatoxin production. Indian Phytopath. 47, 147-152.

13. Jayaraman P and Kalyanasundaram I (1994) Changes in moisture content, mycoflora and aflatoxin content of rice bran during storage. Mycopathologia. 126, 115-121.

14. Jayaraman $P$ and Kalyanasundaram I (1996) Aflatoxin B1 in rice and its products. In: Surveillance, Prevention \& Control of Food Contaminants. Proc. of Natl. Symp., ICMR, New Delhi.

15. Jhonson LF and Curl EA (1972) Methods for research on the ecology of soil borne plant pathogens. Burgess Publ. Company, Minneapolis.

16. Lee LS (1989) Aflatoxin: research, analysis and control. J. Am. Oil Chemists Soc. 66, 1398-1403.

17. Nabney J and Nesbitt BF (1965) A spectrophotometric method for determining the aflatoxins. Analyst. 90, 155160.

18. Pestka JJ, Gaur PK and Chu FS (1980) Quantitation of Aflatoxin B1 and Aflatoxin B1 Antibody by an Enzyme Linked Immunosorbent Microassay. Appl. Environ. Microbiol. 40, 1027-1031.

19. Rao GJ and Kalyanasundaram I (1983) Osmophilism in food grain storage fungi. Mycopathologia. 83, 3-7.

20. Raper KB and Fennel DI (1965) The Genus Aspergillus. The Willium \& Wilkins Company, Baltimore.

21. Raper KB, Thom C and Fennel DI (1949) A manual of the Penicillia. The William \& Wilkins Company, Baltimore.

22. Rukmini C (1985) Chemistry, nutritional and toxicological studies of rice bran oil. Food Chem. 30, 257-268.

23. Sastry GA, Narayana JV, Rama Rao P, Christopher KJ and Hin KR (1965) A report on the groundnut toxicity in murrah buffaloes in Andhra Pradesh (India). Indian Vet. J. 42, 79-82.

24. Seitz LM and Mohr HE (1974) Aflatoxin detection in corn: a simple screening test. Cereal Chem. 51, 487491.

25. Stoloff L, Nasheim S, Yin L, Rodricks JV, Stack N and Campbell AD (1971) A multitoxin method for detection of aflatoxins, ochratoxin, zearalenone, sterigmatocystin and patulin. J. Ass. Anali. Chem. 54, 91-97.

26. Thieu NQ, Ogle B and Peterson $H(2008)$ Screening of aflatoxins and zearalenone in feedstuffs and complete feeds for pigs in Southern Vietnam. Trop Anim. Health Prod. 40(1), 77-83.

27. Vincent Paul Ilangovan (1999) Studies on aflatoxin production in rice: a focus on varietal differences on contamination. Ph.D. Thesis, Univ. of Madras.
Research article

Clndian Society for Education and Environment (iSee)
"Aflatoxin in cattle feed" http://www.indjst.org
Jayaraman \& Indira Indian J.Sci.Technol. 